Int. Arch. Allergy 1959;14:I-V

\title{
Contents, Vol. 14, 1959
}

International Archives of Allergy and Applied Immunology

Supplementum ad vol. 14 (1959)

Experimental Allergic

Encephalomyelitîs and the

"Auto-Allergic" Diseases

By BYRON H. WAKSMAN

Assistant Professor, Department of Bacteriology and Immunology, Harvard Medical

School, and Associate Bacteriologist (Neurology), Massachusetts

BASEL (Switzerland) S. KARGER NEW YORK

General Hospital, Boston, Mass.

19

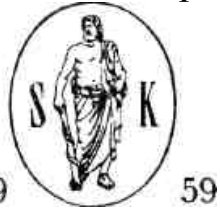

International Archives

of

Allergy and Applied Immunology

Incorporating the Transactions of the Collegium Internationale Allergologicum and the

Proceedings of the International Association of Asthmology and of

National Allergy Societies

A. v. ALBERTINI, Zurich D. BOVET, Roma

C. J. G. BRITTON, London

T. BROMAN, Göteborg

L. BUSINCO, Roma

A. CERLETTI, Basel

H. A. E. v. DISHOECK, Leiden

J. DUCHAINE, Bruxelles

G. ESTRADA DE LA RIVA,

Havana F. J. FARRERONS-CO,

Barcelona

D. G. R. FINDEISEN, Dresden

P. FORMIJNE, Amsterdam

R. A. GOOD, Minneapolis, Minn. F. GRÖER, Krakow W. GRONEMEYER, Bad Lippspringe

A. GRUMBAGH, Zurich M.J. GUTMANN, Jerusalem

CONTRIBUTING EDITORS:

F. HAHN, Düsseldorf

B. HALPERN, Paris 
K. HANSEN, Heide $1 / \frac{1}{8}$ rg E. A. KABAT, New York J. LEGOMTE, Liège

G. LÖFSTRÖM, Uppsala

W. LUTZ, Basel

J. R. MARRAGK, Cambridge

R. MEIER, Basel

J. A. MORETTI, Montevideo

T. OGATA, Tokyo

A. OLIVEIRA-LIMA

Rio de Janeiro D. ORDMAN, Johannesburg W. PAGEL, London M. M. PESHKIN, New York J. R. PRAKKEN, Amsterdam

W. J. QUARLES van UFFORD, Utrecht

A. R. RICH, Baltimore, Md.

B. M. B. RILEY, Sidney

C. RIMINGTON, London

M. ROCHA E SILVA, São Paulo

B. ROSE, Montreal

G. RUIZ MORENO, Buenos Aires

J. RUNNSTRÖM, Stockholm

P. SANGIORGI, Milano

B. SCHICK, New York

H. SCHMIDT, Freiburg/Br.

L. SCHWARTZ, Washington, D.C.

H. SELYE, Montreal

U. SERAFINI, Firenze

A. STOLL, Basel

A. TISELIUS, Uppsala

G. L. WALDBOTT, Detroit, Mich.

R.R.A. Coombs

Cambridge

EDITORS-IN-CHIEF:

D. Harley P. Kallós W. Kaufman

Helsingborg

London

Bridgeport, Conn.

W. Löffler

Zurich

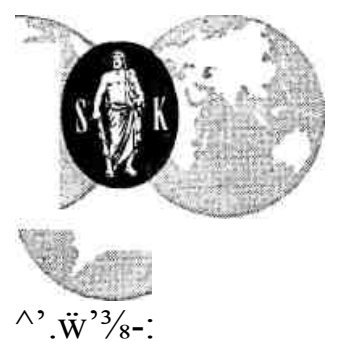

1959 
Vol. 14

\section{BASEL (Schweiz) S. KARGER NEW YORK}

All rights, including that of translation into foreign languages, reserved.

Photomechanic reproduction (photocopy, microcopy) of this book or part of it without special permission of the publishers is prohibited.

(C)

Copyright 1959 by S. Karger AC, Basel. Printed in Switzerland by Buchdruckerei Aargauer Tagblatt AC, Aarau.

Contents - Inhaltsverzeichnis - Sommaire

Alberty, J.: Versuche über den Anteil von Histamin am anaphylaktischen Asthma

sowie Beobachtungen über Auslösung und Verhalten der Asthma- und

Kreislaufsymptome anaphylaktischer Schockfragmente des Meerschwein-

chens 162

Bein, H. J.: vide Jaques, R.

Businco, L.: Connective Tissue, Histio-Capillary Unity and Rheumatism 205

Dobric, V.: vide Inderbitzin, T.

Donald, R. H. O.: Some Clinical Considerations of the Upper Respiratory Tract in Bron

chial Asthma 8

Criep, L. H.: A Consideration of the so-called Collagen or Systemic Connective Tissue Diseases 27

Findeisen, D. G. R.: Zur Rehabilitation des Asthmatikers 97

Fuchs, E.: vide Gronemeyer, W.

Gronemeyer, W. und Fuchs, E.:

Der inhalative Antigen-Pneumometrie-Test als Standard-Methode in der

Diagnose allergischer Krankheiten 217

Hanson, L. Å.: Immunological Analysis of Streptococcal Antigens and Human Sera by means of Diffusion-in-Gel Methods 279

Havens, W. P., Jr.: Liver Disease and Antibody Formation

Hawkins, D. F. and Rosa, L.:

Some Observations on the Release of a Substance Active on the Rat's

Uterus from Guinea-pig Lung during Anaphylactic Shock 312

Herrmann, F.: vide Sulzberger, M. B.

Inderbitzin, T. and Dobric, V.:

Histamine in Skin Anaphylaxis 325

Jaques, R.; Bein, H. J. and Meier, R.:

Influence of Bacterial Polysaccharides and Steroids on the Passive Arthus

Phenomenon in Guinea-Pigs 144

Laborie, F. et Laborie, R.:

Les rapports antigènes-anticorps dans $\Gamma$ allergie tuberculinique, micro-bienne et alimentaire.

(Etude expérimentale sur I'homme et Tanimal) 302

Laborie, R.: vide Laborie, F.

Lind, A.: $\quad$ Serological Studies of Mycobacteria by means of the Diffusion-in-Gel

Technique 1. Preliminary Investigations 264

Meier, R.: vide Jaques, R.

Miller, K.: vide Sulzberger, M. B.

Morrill, S. D.: vide Sulzberger, M. B. 
Olivier, H. R.: A propos de la mesure, dans la maladie asthmatique, des bronchoconstrictions et des broncho-dilatations provoquées 335

Ovary, Z.: Passive Cutaneous Anaphylaxis in the Guinea Pig: Degree of Reaction as a Function of the Quantity of Antigen and Antibody 18

Pascher, F.: vide Sulzberger. M. B.

Prausnitz, C.: Some Remarks on the Past, Present and Future of Allergy

Randolph, T. G.: Musculoskeletal Allergy in Children

84

Rosa, L.: vide Hawkins, D. F.

Roschinsky, W.: vide Schmid, E.

Sanyal, R. K. and West, G. B.:

Sensitizing Properties of Haemophilus Pertussis Vaccine in Laboratory

Animals 241

Sanyal, R. K. and West, G. B.:

Some Effects of X-Irradiation in the White Rat

Schadewaldt, H.: Die Geschichte des Quincke'schen Ödems

Scheiffarth, F.: vide Schmid, E.

Schmid, E.; Scheiffarth, F.; Roschinsky, W. und Zicha, L.:

Über Histamin- und Serotonin-antagonistische Effekte von Antikoagu-lantien.

Wirkungsmechanismus und pathophysiologische Bedeutung . . 292

Sulzberger, M. B.; Herrmann, F.; Morrill, S. D.; Pascher, F. and Miller, K.:

Studies of Sweat, Lipids and Histopathology in Children with "Dry

Skin" (Xerosis) 129

Tiffeneau, R.: Detection d'une production occulte de médiateurs bronchoconstrictifs déclenchée par action allergénique chez Гasthmatique sensibilisé.... 254

Weiss, E.: $\quad$ Emotional Factors in Allergy with Special Reference to Asthma .... 148

West, G. B.: vide Sanyal, R. K.

Zicha, L.: vide Schmid, E.

Proceedings - Gesellschaftsberichte - Sociétés

3ème Congrès International d'Allergologie, Paris $1958 \quad 363$

Seance commune de la Société Néerlandaise et la Société Beige d'Aller gologie, Anvers 1959365

Book Reviews - Buchbesprechungen - Livres Nouveaux

News Items - Nachrichten - Nouvelles

379

Obituary - Nachruf - Necrologue

Dr. Dr. h.c. Heinz Karger $\uparrow$ after - nach - après 240

Béla Schíck

Anniversary Number in Honor of His 80th Birthday

edited by

WILLIAM KAUFMAN 